Asian Review of Social Sciences

ISSN: 2249-6319 Vol.7 No.2, 2018, pp. 50-56

(C) The Research Publication, www.trp.org.in

\title{
Quality of Work Life of Women Employees in Fireworks and Match Industries in Sivakasi, Tamil Nadu
}

\author{
R. Padmaja \\ PG and Research Department of Commerce, AyyaNadarJanakiAmmal College, Sivakasi, Tamil Nadu, India \\ E-Mail: padmaja.r.bcom@gmail.com
}

\begin{abstract}
Generally the quality of work life of employees is based on Hours of work and arrangements of working time; Work organization and job content; Impact of new technologies on working conditions; Working conditions of women, young workers, older workers and other special categories; Work-related welfare services and facilities. This paper highlights about the quality of work life of the women employees working in the various fireworks and match industries in Sivakasi. Keywords: QWL, Fireworks, Match works
\end{abstract}

\section{INTRODUCTION}

Quality of work life is a broad concept and it refers to the degree to which work provides an opportunity for an individual to satisfy the personal needs such as to survive with some security, to interact with others, to be recognized for achievement and to have an opportunity to improve one's skill and knowledge. The concept of quality of work life in short is related to job satisfaction, humanization, work or individualizing the organization and organization development programs.

The present era is an era of knowledge workers and the society in which we are living has come, to be known as knowledge society. The intellectual pursuits have taken precedence over the physical efforts. Some workers work for more than 60 hours a week. As a result of this, their personal hobbies and interests clash with their work. Life is a bundle that contains all the strands together and hence there is a need to balance work life with other related issues. One must have both love and work in one's life to make it healthy. With the increasing shift of the economy towards knowledge economy, the meaning and quality of work life has undergone a drastic change.

\section{STATEMENT OF THE PROBLEM}

Quality of work life is considered to be a most important factor that has to be considered in order to maintain a good relationship with the employees. In the study area more number of fireworks and match industrial units are functioning. As many fire accidents are occurring every year in the particular two industries in the study area, it is very essential to study the QWL. These two are industries providing employment opportunity to the daily wage earners, women in particular. Fireworks and match industrial units attract women employees particularly for the reason of punctuality, sincerity and work involvement. Generally, productivity of these two industries is based on the number of women employees. The researcher has undertaken this study to analyse the quality of work life of women employees working in these two industries, with the aim of to identify the existing Quality of Work Life and offer suggestions to improve the Quality of Work Life of women employees.

\section{REVIEW OF LITERATURE}

Harish Metha and R. Thandavan (2011) conducted a study on "Work Environment Factors in QWL among College Teachers in Chennai", and identified factors of job analysis, organizational culture, educational climate and welfare measurements. The QWL depends on these factors. The scholars suggested that the need to improve physical working environment, coordination, personal goal, institutional goals, and also internal and external environment, interrelations are influencing the working environment.

Mohan and Ashok (2011) in their study, "Measuring of Quality of Work Life in Textile Industries - An Integration of Conceptual Relationship with Productivity",analyzed the drastic role of quality of work life on employees' work performance with reference to the employees of weaving mills. This study covers three major factors of quality of work life, such as welfare facilities, growth opportunities and interpersonal relationship to assess the most appropriate aspect that helps for extracting best performance from the workers. The results of the study implied that the welfare measures have important implications for the employees' job performance as well as the interpersonal relations and growth opportunities may inspire the employees' work performance. These factors may be taken into account in case of future study while determining the quality of work life in an organization.

Mohanasundaram (2011) conducted "A Study on Quality of Work Life in Tamil Nadu Newsprint andPaper Limited, Karur". The factors considered for the study are safe and healthy working conditions, adequate and fair compensation, opportunities to use and develop human capacities, opportunities for career growth, social relevance of work, social integration in the work force, work and 
quality of life, constitutionalism in the work place organization and welfare measures. The study revealed that most of the employees are satisfied with the pay and future career prospects provided by their company than other aspects. This kind of studies is very essential in all sectors to make the organizations aware of their position and make them follow the necessary quality of work life measures to attain better performance.

PremaManoharan (2011) conducted a study on "Quality of Work Life among Bank Professionals: A Study Undertaken at Indian Bank, Chennai", and identified seven factors. They are: pay, employee benefits, job security, alternative work schedules, occupational stress, and participation and democracy in the workplace. The study revealed that the pay is the most unsatisfactory issue, and the remaining other factors such as job satisfaction, occupational stress, alternative work schedules have reached their satisfactory levels but the general awareness about welfare measures is low. Trade unions and the management have to provide several facilities, improve the interpersonal relations, and reduce stress.

Celia. B. R. and Karthick. M. (2012) conducted "A study on the Quality of Work Life of IT Professionals in Chennai". They identified the satisfaction on various factors related to the Quality of Work Life and the perceptions. They are working conditions, hours of work, welfare measures, job security, salary and rewards, skill development, opportunity for growth and superior subordinate relationship. The study revealed that the IT companies should provide a conductive environment for IT professionals to work in the organization, which helps the employees to contribute their best to the company benefiting the nation at a large.

Chitale. C.M and DeeptiLele (2012) conducted an empirical study on "Employees perception on Quality of Work Life in Police Department with Special Reference to Pune Police". Examined police employees and their personal life, and they identified suitable QWL factors in Police Department, viz, work profile, perception of police about their position in society, family life, personal growth and wellness. The study suggested that the Police Department has to improve working conditions, innovative training with adaptation of new technologies and creating satisfaction of economical, social, psychological needs and reducing stress in junior level personnel.

\section{SCOPE OF THE STUDY}

Quality of work life has become the watchword in today's industrial scene, because when there is a proper quality of work life for the employees it will lead to the satisfaction of the employees. More amount of attrition in these two industrial units affect the quality of work life of the employees, women in particular. Hence the researcher has made an attempt to explore various dimensions of Quality of Work Life (QWL) and factors affecting quality of work life of the women employees of fireworks and match industrial units in the study area.

\section{OBJECTIVES}

The following are the objectives of the study

1. To examine the socio-economic profile of the respondents.

2. To analyse the Quality of Work Life of the women employees selected for the study.

3. To offer suitable suggestions for the improvement of Quality of Work Life of the women employees working in these industries than the existing level.

\section{HYPOTHESES}

1. There is no significant association between work status of the respondents and their Various Satisfaction level.

2. There is no significant association between work status of the respondents and their satisfaction.

\section{METHODOLOGY}

The present study is based on both primary and the secondary data.

\section{A. Primary Data}

The study is mainly based on primary data. The primary data is derived from the views obtained from the respondents with the help of pre tested interview schedule.

\section{B. Secondary Data}

The study also depends on the secondary data regarding the history of fireworks and match works in India. The secondary data were collected from standard text books, journals and websites.

\section{SAMPLE SIZE}

Data is collected from the 180 women employees working in the fireworks and match industrial units functioning in the study area. These 180 employees are selected by using snow ball sampling technique.

\section{ANALYSIS AND INTREPRETATION OF DATA}

\section{A. Work Experience}

TABLE I WORK EXPERIENCE

\begin{tabular}{|c|l|c|c|}
\hline $\begin{array}{c}\text { S. } \\
\text { No. }\end{array}$ & $\begin{array}{c}\text { Work } \\
\text { Experience }\end{array}$ & $\begin{array}{c}\text { No. of } \\
\text { Respondents }\end{array}$ & Percentage \\
\hline 1 & $\begin{array}{l}\text { Below } 2 \\
\text { years }\end{array}$ & 18 & 10.00 \\
\hline 2 & 2-4 years & 40 & 22.20 \\
\hline 3 & 4-6 years & 46 & 25.60 \\
\hline 4 & $\begin{array}{l}\text { Above } 6 \\
\text { years }\end{array}$ & 76 & 42.20 \\
\hline \multicolumn{2}{|r|}{ Total } & 180 & 100.00 \\
\hline
\end{tabular}


It is found that most of the respondents (42.20 per cent) have above 6 years of work experience.

\section{B. Association between Work Experience And Opinion About Overall QWL}

To know the significant association between experience and opinion about Overall QWL analysis has been made with the following hypothesis.

\section{Hypothesis}

"There is no significant association between experience of the respondents and their Opinion about Overall QWL".

To test the above hypothesis Chi-Square Test is applied and the result is presented in the following tables.

TABLE II WORK EXPERIENCE AND SATISFACTION TOWARDS OVERALL QUALITY OF WORK LIFE - CROSS TABULATION

\begin{tabular}{|c|c|c|c|c|c|c|}
\hline \multirow{2}{*}{ S. No. } & \multirow{2}{*}{\multicolumn{2}{|c|}{ Work Experience }} & \multicolumn{3}{|c|}{ Satisfaction Towards QWL } & \multirow{3}{*}{$\begin{array}{c}\text { Total } \\
18\end{array}$} \\
\hline & & & Fair & Satisfied & Highly Satisfied & \\
\hline \multirow{3}{*}{1} & \multirow{3}{*}{ Below 2 years } & Count & 2 & 12 & 4 & \\
\hline & & Expected Count & 2.2 & 13.4 & 2.4 & 18.0 \\
\hline & & $\%$ of Total & $1.1 \%$ & $6.7 \%$ & $2.2 \%$ & $10.0 \%$ \\
\hline \multirow{3}{*}{2} & \multirow{3}{*}{$2-4$ years } & Count & 0 & 34 & 6 & 40 \\
\hline & & Expected Count & 4.9 & 29.8 & 5.3 & 40.0 \\
\hline & & $\%$ of Total & $.0 \%$ & $18.9 \%$ & $3.3 \%$ & $22.2 \%$ \\
\hline \multirow{3}{*}{3} & \multirow{3}{*}{ 4-6 years } & Count & 8 & 32 & 6 & 46 \\
\hline & & Expected Count & 5.6 & 34.2 & 6.1 & 46.0 \\
\hline & & $\%$ of Total & $4.4 \%$ & $17.8 \%$ & $3.3 \%$ & $25.6 \%$ \\
\hline \multirow{3}{*}{4} & \multirow{3}{*}{ Above 6 years } & Count & 12 & 56 & 8 & 76 \\
\hline & & Expected Count & 9.3 & 56.6 & 10.1 & 76.0 \\
\hline & & $\%$ of Total & $6.7 \%$ & $31.1 \%$ & $4.4 \%$ & $42.2 \%$ \\
\hline & \multirow{3}{*}{ Total } & Count & 22 & 134 & 24 & 180 \\
\hline & & Expected Count & 22.0 & 134.0 & 24.0 & 180.0 \\
\hline & & $\%$ of Total & $12.2 \%$ & $74.4 \%$ & $13.3 \%$ & $100.0 \%$ \\
\hline
\end{tabular}

TABLE III ASSOCIATION BETWEEN EXPERIENCE AND OPINION ABOUT OVERALL QWL - RESULT OF CHI-SQUARE TEST

\begin{tabular}{|l|c|c|c|}
\hline \multicolumn{4}{|c|}{ Chi-Square Tests } \\
\hline & Value & df & $\begin{array}{c}\text { Asymp. } \\
\text { Sig. } \\
\text { (2-sided) }\end{array}$ \\
\hline Pearson Chi-Square & 9.204 & 6 & .162 \\
\hline Likelihood Ratio & 13.743 & 6 & .033 \\
\hline Linear-by-Linear Association & 4.059 & 1 & .044 \\
\hline N of Valid Cases & 180 & & \\
\hline
\end{tabular}

From the above result of Chi-Square Test it is found that the employees are not varied in the opinion about Overall QWL when they are classified based on the experience. That is the significance value is more than 0.05 . Hence the null hypothesis is accepted and it is concluded that there is no significant association between the work experience of the respondents and their opinion about the Overall QWL.

\section{Overall Satisfaction of the Employees}

The researcher has analyzed the Overall Satisfaction of Employees. In this regard the researcher has used the weighted Arithmetic Mean score value. The results and the allocation of points are given below.

\section{Result}

$\begin{array}{ll}\text { For Highly Satisfied } & =5 \text { points } \\ \text { For Satisfied } & =4 \text { points } \\ \text { For No opinion } & =3 \text { points } \\ \text { For Dissatisfied } & =2 \text { points } \\ \text { For Highly Dissatisfied } & =1 \text { points }\end{array}$


TABLE IV OVERALL SATISFACTION OF EMPLOYEES

\begin{tabular}{|c|l|c|c|c|c|c|c|}
\hline S. No. & \multicolumn{1}{|c|}{ Particulars } & HS & S & NO & DS & HDS & Total \\
\hline 1 & Satisfaction towards Bonus & 0 & 114 & 56 & 10 & 0 & 180 \\
\hline 2 & Satisfaction towards Safety measures & 22 & 116 & 30 & 10 & 2 & 180 \\
\hline 3 & Satisfaction towards Infrastructural Facilities & 30 & 120 & 26 & 4 & 0 & 180 \\
\hline 4 & Satisfaction towards First Aid Facilities & 24 & 108 & 36 & 12 & 0 & 180 \\
\hline 5 & Satisfaction towards relationship with Co-workers & 54 & 120 & 4 & 2 & 0 & 180 \\
\hline 6 & Satisfaction towards relationship with employers & 54 & 98 & 26 & 2 & 0 & 180 \\
\hline 7 & Satisfaction towards QWL & 24 & 134 & 22 & 0 & 0 & 180 \\
\hline 8 & Satisfaction towards wages & 8 & 105 & 59 & 8 & 0 & 180 \\
\hline
\end{tabular}

TABLE V WEIGHTED AVERAGE ARITHMETIC MEAN

\begin{tabular}{|c|l|l|l|l|l|l|l|}
\hline S. No. & \multicolumn{1}{|c|}{ Particulars } & HS & \multicolumn{1}{|c|}{ S } & NO & DS & HDS & Total \\
\hline 1. & Satisfaction towards Bonus & 0 & 456 & 168 & 20 & 0 & 644 \\
\hline 2. & Satisfaction towards Safety measures & 110 & 464 & 90 & 20 & 2 & 686 \\
\hline 3. & Satisfaction towards Infrastructural Facilities & 150 & 480 & 78 & 8 & 0 & 716 \\
\hline 4. & Satisfaction towards First Aid Facilities & 120 & 432 & 108 & 24 & 0 & 684 \\
\hline 5. & Satisfaction towards relationship with Co-workers & 270 & 480 & 12 & 4 & 0 & 766 \\
\hline 6. & Satisfaction towards relationship with employers & 270 & 392 & 78 & 4 & 0 & 744 \\
\hline 7. & Satisfaction towards QWL & 120 & 536 & 66 & 0 & 0 & 722 \\
\hline 8. & Satisfaction towards wages & 40 & 420 & 177 & 16 & 0 & 653 \\
\hline
\end{tabular}

TABLE VI RANKING THE OVERALL SATISFACTION

\begin{tabular}{|c|l|l|l|}
\hline S. No. & \multicolumn{1}{|c|}{ PARTICULARS } & WAM & RANK \\
\hline 1. & Satisfaction towards Bonus & 3.58 & VIII \\
\hline 2. & Satisfaction towards Safety measures & 3.81 & V \\
\hline 3. & Satisfaction towards Infrastructural Facilities & 3.98 & IV \\
\hline 4. & Satisfaction towards First Aid Facilities & 3.80 & VI \\
\hline 5. & Satisfaction towards relationship with Co-workers & 4.26 & I \\
\hline 6. & Satisfaction towards relationship with employers & 4.13 & II \\
\hline 7. & Satisfaction towards overall QWL & 4.01 & III \\
\hline 8. & Satisfaction towards wages & 3.63 & VII \\
\hline
\end{tabular}

The above scaling technique shows that Satisfaction towards relationship with Co-workers is ranked first, followed by the Satisfaction towards relationship with employers, Third rank is given to Satisfaction towards overall QWL attracts the respondents, followed by the Infrastructural Facilities, Safety measures, First Aid Facilities, wages and then by bonus. From the above analysis, it is clearly indicated that most of the employees are satisfied by the relationship with the co-workers.

\section{Facilities Offered in the Working Place}

The respondents are asked to rank their responses about the facilities offered in the working place to them. To identify the most effective facilities offered to the respondents, the researcher has used Garret's ranking test. Based on the facilities offered in the working place the following classification is made

\section{Garrett Scores}

The Garrett ranks are calculated by using appropriate Garrett ranking formula. First, the percent positions are calculated by using appropriate Garrett ranking formula. Then based on the facilities offered, the Garrett values are ascertained. The Garrett value and scores of each facilities offered are multiplied to find out the Garrett scores for each sources. Finally, by adding each row, the total Garrett scores have been obtained. 
Percent position $=100(\mathrm{Rij}-0.5) / \mathrm{Nj}$

$\mathrm{Rij}=$ Rank given for ith item by the $\mathrm{j}^{\text {th }}$ sample respondents

$\mathrm{Nij}=$ Total rank given by the $\mathrm{j}^{\text {th }}$ sample respondents

TABLE VII FACILITIES OFFERED IN THE WORKING PLACE

\begin{tabular}{|c|l|c|c|c|c|c|c|c|c|}
\hline \multirow{2}{*}{ S. No. } & \multirow{2}{*}{ Facilities Offered } & \multicolumn{7}{|c|}{ Rank } & \multirow{2}{*}{ Total } \\
\cline { 3 - 11 } & & I & II & III & IV & V & VI & VII & \\
\hline 1 & Transport facilities & 22 & 30 & 10 & 26 & 52 & 8 & 32 & 180 \\
\hline 2 & Restroom facilities & 42 & 52 & 68 & 12 & 4 & 2 & - & 180 \\
\hline 3 & Ventilation facilities & 36 & 28 & 56 & 42 & 10 & 8 & - & 180 \\
\hline 4 & Medical facilities & 20 & 28 & 18 & 74 & 38 & 2 & - & 180 \\
\hline 5 & Water facilities & 58 & 42 & 22 & 18 & 20 & 14 & 6 & 180 \\
\hline 6 & Housing facilities & 2 & - & - & 4 & 42 & 86 & 46 & 180 \\
\hline 7 & Education to employees children & - & - & 6 & 4 & 14 & 60 & 96 & 180 \\
\hline & \multicolumn{1}{|c}{ Total } & 180 & 180 & 180 & 180 & 180 & 180 & 180 & \\
\hline
\end{tabular}

TABLE VIII GARRETT SCORES -PERCENT POSITION AND GARRETT VALUE

\begin{tabular}{|c|c|c|c|}
\hline S. No. & $\mathbf{1 0 0}(\mathbf{R I J}-\mathbf{0 . 5}) / \mathbf{N J}$ & $\begin{array}{c}\text { Calculated } \\
\text { Value }\end{array}$ & $\begin{array}{c}\text { Garrett } \\
\text { Value }\end{array}$ \\
\hline 1. & $100(1-0.5) / 7$ & 7.14 & 79 \\
\hline 2. & $100(2-0.5) / 7$ & 21.43 & 66 \\
\hline 3. & $100(3-0.5) / 7$ & 35.71 & 57 \\
\hline 4. & $100(4-0.5) / 7$ & 50.00 & 50 \\
\hline 5. & $100(5-0.5) / 7$ & 64.29 & 43 \\
\hline 6. & $100(6-0.5) / 7$ & 78.57 & 34 \\
\hline 7. & $100(7-0.5) / 7$ & 92.86 & 21 \\
\hline \multicolumn{4}{|c|}{ Source: Computed data } \\
\hline
\end{tabular}

TABLE IX CALCULATION OF GARRETT SCORE

\begin{tabular}{|c|c|c|c|c|c|c|c|c|c|}
\hline \multirow{2}{*}{ S. No. } & \multirow{2}{*}{ Facilities } & \multicolumn{7}{|c|}{ Rank } & \multirow{2}{*}{ Total } \\
\hline & & I & II & III & IV & $\mathbf{V}$ & VI & VII & \\
\hline 1. & Transport facilities & $\begin{array}{l}22 * 79 \\
=1738\end{array}$ & $\begin{array}{l}30 * 66 \\
=1980\end{array}$ & $\begin{array}{c}10 * 57 \\
=570\end{array}$ & $\begin{array}{l}26 * 50 \\
=1300\end{array}$ & $\begin{array}{l}52 * 43 \\
=2236\end{array}$ & $\begin{array}{l}8 * 34 \\
=272\end{array}$ & $\begin{array}{c}32 * 21 \\
=672\end{array}$ & 8768 \\
\hline 2. & Restroom facilities & $\begin{array}{l}42 * 79 \\
=3318\end{array}$ & $\begin{array}{l}52 * 66 \\
=3432 \\
\end{array}$ & $\begin{array}{l}68 * 57 \\
=3876\end{array}$ & $\begin{array}{l}12 * 50 \\
=600\end{array}$ & $\begin{array}{l}4 * 43 \\
=172 \\
\end{array}$ & $\begin{array}{c}2 * 34 \\
=68\end{array}$ & $\begin{array}{c}0 * 21 \\
=0\end{array}$ & 11466 \\
\hline 3. & Ventilation Facilities & $\begin{array}{l}36 * 79 \\
=2844\end{array}$ & $\begin{array}{l}28 * 66 \\
=1848\end{array}$ & $\begin{array}{l}18 * 57 \\
=3192\end{array}$ & $\begin{array}{l}42 * 50 \\
=2100\end{array}$ & $\begin{array}{c}10 * 43 \\
=430\end{array}$ & $\begin{array}{l}8 * 34 \\
=272\end{array}$ & $\begin{array}{c}0 * 21 \\
=0\end{array}$ & 10686 \\
\hline 4. & Medical Facilities & $\begin{array}{l}20 * 79 \\
=1580\end{array}$ & $\begin{array}{l}28 * 66 \\
=1848\end{array}$ & $\begin{array}{c}13 * 57 \\
=741\end{array}$ & $\begin{array}{l}74 * 50 \\
=3700\end{array}$ & $\begin{array}{l}38 * 43 \\
=1634\end{array}$ & $\begin{array}{c}2 * 34 \\
=68\end{array}$ & $\begin{array}{c}0 * 21 \\
=0\end{array}$ & 9422 \\
\hline 5. & Water Facilities & $\begin{array}{l}58 * 79 \\
=4582\end{array}$ & $\begin{array}{l}42 * 66 \\
=2771\end{array}$ & $\begin{array}{l}8 * 57 \\
=456\end{array}$ & $\begin{array}{c}18 * 50 \\
=900\end{array}$ & $\begin{array}{c}20 * 43 \\
=860\end{array}$ & $\begin{array}{c}14 * 34 \\
=476\end{array}$ & $\begin{array}{l}6 * 21 \\
=126\end{array}$ & 10970 \\
\hline 6. & Housing Facilities & $\begin{array}{l}2 * 79 \\
=158\end{array}$ & $\begin{array}{c}0 * 66 \\
=0\end{array}$ & $\begin{array}{l}12 * 57 \\
=684\end{array}$ & $\begin{array}{l}4 * 50 \\
=200 \\
\end{array}$ & $\begin{array}{l}42 * 43 \\
=1806\end{array}$ & $\begin{array}{l}86 * 34 \\
=2924\end{array}$ & $\begin{array}{c}46 * 21 \\
=966\end{array}$ & 6054 \\
\hline 7. & Education to employees children & $\begin{array}{c}0 * 79 \\
=0\end{array}$ & $\begin{array}{c}14 * 66 \\
=0\end{array}$ & $\begin{array}{l}13 * 57 \\
=741 \\
\end{array}$ & $\begin{array}{l}4 * 50 \\
=200\end{array}$ & $\begin{array}{l}14 * 43 \\
=602\end{array}$ & $\begin{array}{l}60 * 34 \\
=2040\end{array}$ & $\begin{array}{l}96 * 21 \\
=2016\end{array}$ & 5200 \\
\hline
\end{tabular}

The above table shows that the Garret scores. First the Garret values are calculated by using appropriate Garret ranking formula. Then based on the Garret values, the Garret table scores are ascertained. The Garret values and the scores of facilities offered in table IX are multiplied to find out score. Finally by adding each row, the total Garret scores are obtained. 
TABLE X FACILITIES OFFERED IN THE WORKING PLACE GARRETT RANKING

\begin{tabular}{|c|c|c|c|}
\hline $\begin{array}{l}\text { S. } \\
\text { No. }\end{array}$ & $\begin{array}{c}\text { Facilities } \\
\text { Offered }\end{array}$ & Garrett Score & Garrett Rank \\
\hline 1. & $\begin{array}{l}\text { Transport } \\
\text { facilities }\end{array}$ & 8768 & V \\
\hline 2. & $\begin{array}{l}\text { Restroom } \\
\text { facilities }\end{array}$ & 11466 & I \\
\hline 3. & $\begin{array}{l}\text { Ventilation } \\
\text { facilities }\end{array}$ & 10686 & III \\
\hline 4. & $\begin{array}{l}\text { Medical } \\
\text { Facilities }\end{array}$ & 9422 & IV \\
\hline 5. & Water Facilities & 10970 & II \\
\hline 6. & $\begin{array}{l}\text { Housing } \\
\text { Facilities }\end{array}$ & 6054 & VI \\
\hline 7. & $\begin{array}{l}\text { Education to } \\
\text { employees } \\
\text { children }\end{array}$ & 5200 & VII \\
\hline
\end{tabular}

The above table shows that the scores for facilities offered. The Garrett scores are ranked according to their values. The I rank is given for Restroom facilities, II rank is given for water facilities, III rank is given for ventilation facilities, IV rank is given for medical facilities, $V$ rank is given for transport facilities, VI rank is given for housing facilities and VII rank is given for education to employees' children.

\section{Association between Work Status and Various} Satisfaction Levels of the Employees

To know the Association between Work status and Satisfaction level of the employees' analysis has been made with the following hypothesis.

\section{Hypothesis}

"There is no significant association between work status of the respondents and their satisfaction".

To test the above hypothesis Kruskal-Wallis test is applied and the result is presented in the following tables.

From the above result of Kruskal-Wallis Test it is found that the employees are varied in the satisfaction towards safety measures, infrastructural facilities, first aid, relationship with employers and co-workers and Quality of Work Life when they are classified based on their job status.

That is the significance value is less than 0.05 . Hence the null hypothesis is rejected and it is concluded that there is a significant association between the work status of the employees and their various satisfaction level.
TABLE XI ASSOCIATION BETWEEN WORK STATUS AND VARIOUS SATISFACTION LEVEL OF THE EMPLOYEES - RESULT OF KRUSKAL-WALLIS TEST-RANKS

\begin{tabular}{|c|c|c|c|}
\hline Factors & Work Status & $\mathbf{N}$ & $\begin{array}{l}\text { Mean } \\
\text { Rank }\end{array}$ \\
\hline \multirow{4}{*}{ Satisfaction towards Bonus } & Temporary & 26 & 94.81 \\
\hline & Contract & 56 & 81.68 \\
\hline & Permanent & 98 & 94.40 \\
\hline & Total & 180 & \\
\hline \multirow{4}{*}{$\begin{array}{l}\text { Satisfaction towards Safety } \\
\text { Measures }\end{array}$} & Temporary & 26 & 61.73 \\
\hline & Contract & 56 & 82.25 \\
\hline & Permanent & 98 & 102.85 \\
\hline & Total & 180 & \\
\hline \multirow{4}{*}{$\begin{array}{l}\text { Satisfaction towards } \\
\text { Infrastructural Facilities }\end{array}$} & Temporary & 26 & 65.88 \\
\hline & Contract & 56 & 77.61 \\
\hline & Permanent & 98 & 104.40 \\
\hline & Total & 180 & \\
\hline \multirow{4}{*}{$\begin{array}{l}\text { Satisfaction towards First Aid } \\
\text { Facilities }\end{array}$} & Temporary & 26 & 61.42 \\
\hline & Contract & 56 & 77.43 \\
\hline & Permanent & 98 & 105.68 \\
\hline & Total & 180 & \\
\hline \multirow{4}{*}{$\begin{array}{l}\text { Satisfaction towards } \\
\text { relationship with Co-workers }\end{array}$} & Temporary & 26 & 106.65 \\
\hline & Contract & 56 & 75.82 \\
\hline & Permanent & 98 & 94.60 \\
\hline & Total & 180 & \\
\hline \multirow{4}{*}{$\begin{array}{l}\text { Satisfaction towards } \\
\text { relationship with employers }\end{array}$} & Temporary & 26 & 107.81 \\
\hline & Contract & 56 & 65.21 \\
\hline & Permanent & 98 & 100.36 \\
\hline & Total & 180 & \\
\hline \multirow{4}{*}{$\begin{array}{l}\text { Satisfaction towards overall } \\
\text { QWL }\end{array}$} & Temporary & 26 & 95.58 \\
\hline & Contract & 56 & 75.64 \\
\hline & Permanent & 98 & 97.64 \\
\hline & Total & 180 & \\
\hline \multirow{4}{*}{ Satisfaction towards wages } & Temporary & 26 & 97.15 \\
\hline & Contract & 56 & 89.25 \\
\hline & Permanent & 98 & 89.45 \\
\hline & Total & 180 & \\
\hline
\end{tabular}


TABLE XII ASSOCIATION BETWEEN WORK STATUS AND VARIOUS SATISFACTION LEVEL OF THE EMPLOYEES KRUSKAL-WALLIS TEST

\begin{tabular}{|l|c|c|c|}
\hline \multicolumn{1}{|c|}{ Factors } & Chi Square & Df & $\begin{array}{c}\text { Asymp. Sig. } \\
\text { (2-tailed) }\end{array}$ \\
\hline Satisfaction towards Bonus & 3.257 & 2 & .196 \\
\hline Satisfaction towards Safety Measures & 20.438 & 2 & .000 \\
\hline Satisfaction towards Infrastructural Facilities & 23.278 & 2 & .000 \\
\hline Satisfaction towards First Aid Facilities & 25.787 & 2 & .000 \\
\hline Satisfaction towards relationship with Co-workers & 11.158 & 2 & .004 \\
\hline Satisfaction towards relationship with employers & 24.194 & 2 & .000 \\
\hline Satisfaction towards overall QWL & 11.387 & 2 & .003 \\
\hline Satisfaction towards wages & .648 & 2 & .723 \\
\hline
\end{tabular}

\section{FINDINGS OF THE STUDY}

The following are findings of the study.

1. Most of the respondents (42.20 per cent) have above 6 years of work experience.

2. There is a significant association between the age of the respondents and their work stress.

3. Satisfaction towards relationship with Co-workers is ranked first, followed by the Satisfaction towards relationship with employers, Third rank is given to Satisfaction towards QWL attracts the respondents , followed by the Infrastructural Facilities, Safety measures, First Aid Facilities, wages and then by bonus.

4. The I rank is given for Restroom facilities, II rank is given for water facilities, III rank is given for ventilation facilities, IV rank is given for medical facilities, $\mathrm{V}$ rank is given for transport facilities, VI rank is given for housing facilities and VII rank is given for education to employees' children.

\section{SUGGESTIONS}

The researcher has offered the following suggestions based on the above findings.

1. Education to the children of employees can be provided as it ranks last in the facilities provided to the employees

2. Safety measures can be given to the employees by means of providing them with facial mask and gloves which make the employees feel safer and highly satisfied regarding the safety measures.
3. Bonus and wages can be increased in the short run as the employees are feeling that was not mere sufficient for them.

\section{CONCLUSION}

From the study it is understood that the QWL of the employees of fireworks and match works industry in Sivakasi is based on the various factors like relationship with owners and co-workers, income, bonus, working time and welfare measures. If the above suggestions offered by the researcher are considered by the employers of the fireworks and match works industry, QWL of the employees of the match works industry will be improved.

\section{REFERENCES}

[1] www.yourarticlelibrary.com

[2] Harish Metha \& Thandavan. R., (2011). Work Environment Factors in QWL among College Teachers in Chennai, Southern Economist, 50 (12), 15-18.

[3] Mohan \& Ashok, Measuring of Quality of Work Life in Textile Industries - An Integration of Conceptual Relationship with Productivity. (2011).International Journal of Research in Commerce and Management, 2(4), 67-70.

[4] Mohanasundaram. (2011).A Study on Quality of Work Life in Tamil Nadu Newsprint andPaper Limited, Karur. International Journal of Research in Computer Application \& Management, 1(8), 53-58.

[5] Prema Manoharan. (2011).Quality of Work Life among Bank Professionals: A Study Undertaken at Indian Bank, Chennai", International Journal of Research in Commerce, Economic \& Management1. 1(8), 69-74.

[6] Celia. B.R \& Karthick. M. (2012). A Study on Quality of Work Life in the IT Sector. Asia Pacific Journal of Research in Business Management, APJRBM, 3(2), 27-35.

[7] Chitale, C.M \& DeeptiLele. (2012). Employees perception on Quality of Work Life in Police Department with Special Reference Pune Police. South Asian Academic Research Journal, An International Multidisciplinary Research Journal, ACADEMICIA, 2(10),260-275. 